\title{
Caste and Diaspora
}

\author{
Singh Swapnil
}

\begin{abstract}
This paper as entitled-"Caste and Diaspora" talks about the caste system, its characteristics and also the kind of importance it holds in Indian society. But most importantly, it focuses on the importance of caste system which can be seen among the Indian Diaspora. The institution of caste as it reinforces itself among Indians residing abroad. The caste as a system might be dying in India but caste as an identity is getting stronger day by day and this 'identity' per se becomes the basis of discriminatory behavior towards the other caste members. The strong urge to marry their sons and daughters within their caste very well shows the hold of caste identity present among the Indian Diaspora. Even the upward mobility in the status ladder also does not guarantee the change of attitude towards the other caste members, when it comes to marriage proceedings.
\end{abstract}

Index Terms - Caste, Diaspora, Jati, Varna.

\section{INTRODUCTION}

All human beings are born free and equal in dignity and rights. They are endowed with reason and conscience and should act towards one another in a spirit of brotherhood.

India is a classical land of the caste. It is here, in India, we find more than 2800 castes and sub-castes with all their peculiarities. Of these, the major caste (previously known as Varna) such as Brahmins, Kshatriya, Vaishyas and Shudras (or depressed caste) are found in almost all the states. The term 'caste' is derived from the Portuguese word 'caste' meaning 'breed' or 'lineage'. The Portuguese used the term 'caste' first to denote the divisions in the Indian caste system. The word 'caste' also signifies 'race' or 'kind'. The Sanskrit word for caste is 'Varna' which means 'color'. Races and color seem to be the bases of Indian caste in addition to the division of labor and occupation and more than division of labor, it is division of laborers.

Caste is believed to be the defining feature of India. It is the single most powerful symbol for the Indian social world, rural and urban. Although this 'caste as India' assertion has been questioned and critiqued during the last three decades by anthropologists and historians alike for distorting our understanding of Indian society[1], it remains alive and kicking in everyday consciousness in India and abroad. For social scientists, even when caste is not the sole emblem of 'modern' and 'traditional' India, it is still believed to be central to understanding Indian social reality [2]. Two images of caste are central to this understanding of Indian society: caste as community and caste as maker of dominance and hierarchy laid down at birth.

Manuscript received September 22, 2013; revised November 27, 2013.

Singh Swapnil is with the Centre for the Study of Social Systems, Jawaharlal Nehru University, New Delhi, India (e-mail: swapnil.singh23@gmail.com).

\section{Institution OF CASte System}

The Indian Caste System is historically one of the main dimensions where people in India are socially differentiated through class, religion, region, tribe, gender, and language. Although this or other forms of differentiation exist in all human societies, it becomes a problem when one or more of these dimensions overlap each other and become the sole basis of systematic ranking and unequal access to valued resources like wealth, income, power and prestige. The Indian Caste System is considered a closed system of stratification, which means that a person's social status is obligated to which caste they were born into. There are limits on interaction and behaviour with people from another social status.

According to the most prevalent belief the Brahmans (priests), Kshatriyas (warrior), Vaisyas (merchants) and Sudras (serving class) are said to have been separately created from the mouth, arms, thighs and the feet respectively of the Creator. The oldest extant passage in which this idea occurs is the Purusha Sukta of the tenth book of the Rigveda, though the representation there is somewhat vague. The idea gains wide circulation in the Dharmashastras and the Puranas, and the Manu accepts it without questioning, which is often cited as an authoritative pronouncement on the subject.

The notions of purity and pollution are critical for defining and understanding caste hierarchy. According to these concepts, Brahmins hold the highest rank and Shudras the lowest in the caste hierarchy. The Varna System represents a social stratification which includes four varnas namely- Brahmans, Kshatriya, Vaisya and Shudras. The Shudras were allocated the lowest rank of social ladder and their responsibilities included service of the three Varnas. The superior castes tried to maintain their ceremonial purity

Dumont holds the notion of purity and pollution interlinked with the caste system and untouchability. The hierarchy of caste is decided according to the degree of purity and pollution. It plays a very crucial role in maintaining the required distance between different castes. But the pollution distance varies from caste to caste and from place to place [3].

Dipankar Gupta observes that the notion of purity and pollution as Dumont observed is integrally linked with the institution of untouchability .But unlike untouchability the notion of purity and pollution is also a historical accretion Over time this notion freed itself from its specific and original task of separating untouchables from the others and began to be operative at different planes of the caste system.

Surveying the impact of social and political movements on the Indian caste system in the mid-20th century, theorists of caste were beginning to aver that while castes might still 
exist, the caste system was dying. Caste groups, they argued, were moving away from their more traditional relationships of socio-economic interdependence, and toward more competitive models of social interaction. Citing the writings of Edmund Leach and F.G. Bailey, Dumont writes: "If interdependence is replaced by competition, caste is dead.... There remain groups that one continues to call 'castes'; but they are set in a different system".

It has become a truism today that caste in India has not disappeared in direct proportion to the spread of modern technology. In the rural areas caste, despite many modifications, is persisting in its traditional form, as a system of hierarchically graded, locally integrated, occupationally and ritually specialized, endogamous social strata. In the contemporary, urban-based order, caste is persisting in the form of complex networks of interest groups preserved through endogamy and legitimized by religion. In both forms, caste remains an extremely viable social institution and thus appears to be an instance where simultaneously old uses have been retained and new ones found for a traditional Asian social structure.

In the Discovery of India, Jawaharlal Nehru wrote, "Almost everyone who knows anything at all about India has heard of the caste system; almost every outsider and many people in India condemn it or criticize it as a whole" [4].

Castes are proud of their identity, regardless of where textual traditions place them on the 'purity-pollution' hierarchy [5].

Explaining the process of globalization, Oommen (2003) has emphasized that increase in the impact of a common communication system in the current epoch, has converted the universe into a 'world society'. However, he argues that a world culture is different from a world society. It is different because there are four interrelated processes involved in the creation of what is called the global culture. These are: homogenization; traditionalisation; and hybridization. Hence, to understand the impact of globalization on the Indian society, it is very important to look at how these four processes are at work. In this context, Oommen emphasizes that the vast network of communication system which produces a world society results in the process of homogenization. That means the traits; culture or institutions have all become global.

The process of modernization is a complex one. It is activated by a variety of social, economic and political forces. Among other things, it tends to loosen the rigidity of traditional structure and provide greater choice to individuals which cut across the boundaries of the old, established groups [6], but in some social institutions, the traditional forces still are very much relevant.

The similarity between the practice of apartheid and caste based discrimination can be made where the distinction among people is made on the basis of their birth and ascribed status rather than an achieved one. The Constitution of India guarantees equal rights for every citizen and thereby any kind of discrimination based only on caste or practicing 'untouchability' in any form is an offence punishable under Article 18 of Part III in Indian Constitution. The emergence of "khap" Panchayats in Northern part of India which has been held unconstitutional by the law is strongly supporting caste identities and most of the inter caste marriages lead to death. One of the reasons for the persistence of caste is the fact that the caste has turned into a vote bank.

With the concepts like Secularism, equality and democracy, the Caste system is losing hold of its traditional pattern and is adopting itself to a new social order, suitable to the modern times. Today, no occupation is caste bound, as it traditionally used to be. The constitution, with the 'protective discrimination', tries to assist the social education and economic interests of the Backward Classes. But still the caste names such as "Badhai" (carpenter) and "Dhobi" (washer man) continue to hold its presence and even relevance in today's society as well.

\section{CASTE AMONG INDIAN DIASPORA}

The Indian Diaspora is a generic term to describe the people who migrated from territories that are currently within the borders of the Republic of India. It also refers to their descendants. The Diaspora is currently estimated to number over twenty million, composed of "NRIs" (Indian citizens not residing in India) and "PIOs" (Persons of Indian Origin who have acquired the citizenship of some other country). The Diaspora covers practically every part of the world. It numbers more than a million each in eleven countries, while as many as twenty-two countries have concentrations of at least a hundred thousand ethnic Indians.

"Caste-based exclusion of Dalits has extended to the worldwide Indian Diaspora as well. Here, too, caste discrimination exists in the workplace, educational institutions and everyday interactions. So-called upper castes have refused to employ or work under Dalits in senior positions. Dalits have suffered ridicule of their caste-based names in schools, places of worship, and neighbourhoods. Indian matrimonial centers and websites that cater specially for the Indian Diaspora have classified prospective brides and grooms on the basis of castes and sub-castes" [7].

The caste system, at least amongst the Indian Diaspora, plays an important part in regulating their social conduct. Caste is inextricably linked to the Hindu religion and finds sanction in their sacred literature such as the Ramayana and Mahabharata. It is especially enforced by the Manu Smriti (Laws of Manu) with imposition of severe punishment and penalty for breach of the social code for what was once, in historic times, a legal sanction.

Over the last few decades there has been a gradual increase in population of those who have arrived in United Kingdom from the Indian sub-continent. Those communities that have settled there have also brought with them their own social habits, norms and religious customs, such as the institution of caste. The social evil of casteprejudice, however, is unacceptable in present day British society and is antithetical to democratic norms, values and justice. There is evidence that caste-prejudice is firmly embedding itself into British society as has been shown by a radio programme commissioned by the BBC on Radio 4, The Caste Divide which was broadcast in April, 2003. Subsequent to this programme, it was strongly felt that there was a need to confront the problem of caste and this has lead to the formation of an organisation called 


\section{'CasteWatchUK'.}

This virulent form of discrimination is not restricted exclusively to the Hindu community. Its taint also affects other faiths in the subcontinent and Indo-Pakistani Diaspora including the Sikh, Christian and Muslim communities. Caste prejudice and caste discrimination are unwanted foreign imports that are being spread through many Hindu and Sikh places of worship. Caste discrimination is a violation of the Universal Declaration of Human Rights, (1948).

Caste permeates the whole Diaspora community. Everywhere in the West, advertisements aiming to arrange marriages among the Hindu community will advertise caste as part of the package - age, height, caste, nationality, educational qualifications, profession, and hobbies. Some will state 'caste no bar'; others, including those from socalled 'untouchable' castes, will make statements such as 'Prefers a Ravidasia girl, but will welcome other castes'; 'Khatri Family seeks'; 'Jat Sikh educated family seeks ...'

In North America, large meetings are held with the purpose of getting young people from the same caste to get to know each other. In Atlanta, the Patidar Samaj meeting drew 4,000 people and resulted in 100 marriages. Many people return to South Asia to marry someone from their own caste. A matrimonial agency in Britain, says: 'People are still mentioning the issue of caste and bringing it up when it comes to marriage and generally... people don't want to marry into a lower caste. We also find that those who originate from a lower caste prefer to meet someone of the same background because they know that they may be victimized because they are of a lower caste.' She says that only 25 per cent of marriages take place across caste barriers.

There cannot be one reason which can be referred to as the cause of this discrimination based on caste. It is a common belief that education is the solution for eliminating social evils from our society, but this belief also contradicts itself. The Indian Diaspora population is comparatively much more educated and aware as compared to their counterparts living in India; still they believe and follow the rigid rules and regulations of this evil institution called "caste". Being educated also does not solve this problem because if this was the case then there would be no matrimonial advertisements displaying their caste or mentioning the caste of the prospective bride/groom.

\section{CONCLUSION}

Despite many problems, the caste system has operated successfully for centuries, providing goods and services to India's many millions of citizens. The system continues to operate, but changes are occurring, which can be very well discussed through how occupational mobility has taken place in Indian society and is rather taking place. The space of "castelessness" can be viewed through the changes of occupational choices of contemporary India but still the choices for matrimonial alliances not only in India but also among Diaspora talks to the contrary. How does "caste" find its presence and relevance in today's time and also how does it exists in contemporary India and in a way being reinforced and stringent reactions towards "inter-caste" marriages is an issue that needs to be taken seriously.

The upwards mobility in the status ladder, be it in class context or educational achievements, also does not becomes a distinguishing factor for not believing in caste as an important 'identity' marker. Caste as a system of social organization has been exported from its regions of origin to Diaspora communities, yet despite the prohibition of castebased discrimination in international human rights law caste is not recognized as a ground of discrimination in English law. The new generation has been brought up in the wake of secular institutions and therefore they imbibe the new culture without the importance or much knowledge of caste 'identity' but at the same time the older generation try to reinforce their caste 'identity' when the time comes for marriage ceremonies.

Caste is so much entrenched within the minds that Dr. Ambedkar aptly says that wherever a Hindu goes, he takes his caste along with him. But the unique thing to be noticed is that not only people belonging to Hindu community but also the Sikhs follow these traditional patterns of caste.

The strong form in which caste based discrimination shows itself among Indian Diaspora is a cause of worry. This has to be changed. The social acceptance and the functional utility of caste are being made use of even in contemporary times, and this is true not only for India but is equally true for the Indian Diaspora. The real flaw is the attitude of people which should change, and then only there is some hope of eradicating this deeply embedded social evil.

\section{REFERENCES}

[1] J. H. Hutton, Caste in India: Its Nature, Function and Origins, Indian Branch, Bombay: OUP, 1963, pp. 44-45.

[2] C. J. Fuller, Caste Today, New Delhi: Oxford University Press, 1996, pp. 4-9.

[3] D. Louis, Homo Hierarchicus: The Caste System and Its Implications, United States: University of Chicago Press, 1980, pp. 42-48.

[4] D. B. Nicholas, Castes of Mind: Colonialism and the making of Modern India, India: Princeton University Press, 2002, pp. 3-6.

[5] G. D. Caste, in Question: Identity or hierarchy, New Delhi: Sage Publications, 2004, ch. 1.

[6] B. Andre, Caste, Class, and Power: Changing Patterns of Stratification in a Tanjore Village, Berkeley: University of California, 1965, pp.1-18.

[7] K. Vivek, "Understanding Dalit Diaspora," Economic and Political Weekly, vol. 39, no. 1, pp. 114116, Jan. 3-9, 2004.

[8] B. Celestin, Essays on the Caste System, London: Cambridge University Press, 1971.

[9] R. K. Jain, Nation, Diaspora, Trans-Nation: Reflections from India, India: Routledge, 2010.

[10] R. Parvati, Tracing an Indian Diaspora-Contexts, Memories and Representations, India: Sage Publications, 2008.

[11] Abraham and Susan, "Transcending Caste Barriers," Economic and Political Weekly, vol. XIVI, no. 52, December 24, 2011.

[12] M. Nivedita, "Caste on the international stage," Economic and Political Weekly, vol. XLVI, no. 3, January 15, 2011.

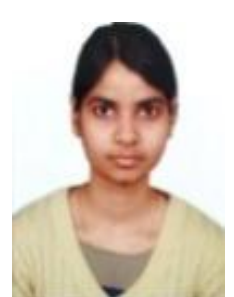

Singh Swapnil was born in Lucknow India on November 11, 1986. She is currently pursuing Ph.D. from Centre for the Study of Social Systems at Jawaharlal Nehru University, New Delhi, India in sociology. She has a publication; Singh, Swapnil, "Caste System: Continuities and Changes," Bangkok, International Proceedings of Economic Development and Research ICHHS II, vol. 64, pp. 70-74, April 2013. Her current research includes the detailed analysis of caste system as prevalent in India and among Indians living abroad and also in the area relevant with functioning of democracy at grass root level in India in the form of Panchayats. Ms. Singh is currently a member of Institute of Social Sciences (India). 